ISSN $1978-3000$

\title{
Pengaruh Penggunaan Talas (Colocasia esculenta) Terhadap Kualitas Telur Itik Talang Benih
}

\author{
The Effect of Taro (Colocasia esculenta) in Feed on Talang Benih Duck Egg Quality \\ Kususiyah, Urip Santoso, dan Debi Irawan
}

Jurusan Peternakan Fakultas Pertanian Universitas Bengkulu

kususiyahkususiyah@yahoo.com

\begin{abstract}
The aim of this research was to evaluate the effect of taro (Colocasia esculenta) on egg quality of Talang Benih duck. Twenty five of laying females of Talang Benih duck were reared in individual cages. Five treatments of feed composition were arranged in a randomized complete design with five replications. Treatments included $87.5 \%$ basal feed with addition of $12.5 \%$ taro, i.e. $35 \%$ leaf $+40 \%$ petiole $+25 \%$ stem (P1), $25 \%$ leaf $+25 \%$ petiole $+50 \%$ stem (P2), $12,5 \%$ leaf $+12,5 \%$ petiole $+50 \%$ stem (P3), $100 \%$ stem (P4), and control, consisted of $100 \%$ basal feed (P0). Measured variables included egg weight, yolk color, thickness of egg shell, and physical composition of egg. The results showed that addition of taro with varied composition in leaf, petiole and stem at $12.5 \%$ feed significantly increased egg weight, improving yolk color, and increasing thickness of egg shell but did not affect of physical composition of egg.

Key Words : Egg Quality, Talang Benih Duck, Taro (Colocasia esculenta)
\end{abstract}

\begin{abstract}
ABSTRAK
Tujuan penelitian ini adalah untuk mengevaluasi pengaruh penggunaan talas (Colocasia esculenta) terhadap kualitas telur Itik Talang Benih. Dua puluh lima ekor Itik Talang Benih sedang produksi dipelihara dalam kandang baterai individual. Rancangan penelitian yang digunakan adalah rancangan acak lengkap 5 perlakuan dengan 5 ulangan. P0 sebagai kontrol menggunakan $100 \%$ ransum basal tanpa menggunakan talas, P1 menggunakan $87,5 \%$ ransum basal $+12.5 \%$ talas (35\% daun $+40 \%$ tangkai daun $+25 \%$ umbi), P2 menggunakan $87,5 \%$ ransum basal $+12,5 \%$ talas $(25 \%$ daun $+25 \%$ tangkai daun $+50 \%$ umbi), P3 menggunakan $87,5 \%$ ransum basal $+12,5 \%$ talas $(12,5 \%$ daun $+12,5 \%$ tangkai daun $+75 \%$ umbi), dan $\mathrm{P} 4$ menggunakan $87,5 \%$ ransum basal $+12,5 \%$ talas $(100 \%$ umbi). Peubah yang diukur meliputi berat telur per butir, warna yolk, tebal kerabang telur, dan komposisi fisik telur. Hasil analisis ragam menunjukkan bahwa penggunaan talas 12,5\% berpengaruh secara nyata terhadap berat telur per butir, warna yolk, dan tebal kerabang telur, tetapi tidak berpengaruh secara nyata terhadap kmposisi fisik telur. Dapat disimpulkan bahwa penggunaan talas dengan berbagai kombinasi penggunaan antara bagian daun, tangkai daun dan umbi sebanyak $12,5 \%$ secara nyata $(\mathrm{P}<0,05)$ meningkatkan berat telur per butir, memperbaiki warna yolk, dan meningkatkan tebal kerabang telur tapi tidak berpengaruh secara nyata $(\mathrm{P}>0,05)$ terhadap komposisi fisik telur.
\end{abstract}

Kata Kunci : Kualitas Telur Itik Talang Benih, Talas (Colocasia esculenta)

\section{PENDAHULUAN}

Biaya pakan dalam industri peternakan merupakan komponen biaya yang paling tinggi. Oleh karena itu diperlukan kejelian peternak untuk dapat memanfaatkan bahan-bahan sumber pakan yang murah agar biaya pakan menjadi lebih rendah tanpa mengurangi performans dan kualitas ternak yang dipelihara. Talas merupakan tanaman yang banyak tumbuh liar di daerah rawa dan belum dimanfaatkan secara optimal. Talas yang merupakan tanaman asli daerah 
tropis telah lama dibudidayakan di Indonesia. Menurut Suhardi (2006), talas mengandung calsium, vitamin A, dan vitamin $C$ jauh lebih baik dibandingkan dengan beras dan gandum. Umbi dan daun talas mengandung karbohidrat, protein, dan lemak (Somantri, 2006). Potensi talas sebagai bahan pakan telah terbukti dengan adanya peternak itik di berbagai daerah yang memberikan talas pada itik yang dipeliharanya. Diyakini bahwa dengan memberikan talas pada pakan itik, dapat mengurangi biaya pakan dan mampu meningkatkan produksi telur itik. Seberapa besar pengaruh penggunaan talas terhadap kualitas telur itik perlu dilakukan penelitian lebih lanjut. Penelitian ini bertujuan untuk mengevaluasi pengaruh penggunaan talas terhadap kualitas telur itik Talang Benih.

\section{MATERI DAN METODE}

Penelitian ini menggunakan Itik Talang Benih betina sedang produksi umur 32 minggu sebanyak 25 ekor. Itik dipelihara pada kandang baterai individual ukuran 40 $\mathrm{cm} \times 25 \mathrm{~cm} \times 40 \mathrm{~cm}$ sebanyak 25 petak. Rancangan penelitian yang digunakan adalah rancangan acak lengkap 5 perlakuan dan 5 ulangan. Ransum disusun iso protein $17 \%$. Susunan ransum basal ditampilkan pada Tabel 2. dan disusun berdasarkan kandungan nutrisi bahan penyusun ransum (Tabel 1.). Komposisi ransum perlakuan ditampilkan pada Tabel 3.

\section{Teknik Pemberian Talas}

Daun, tangkai daun, dan umbi talas dicuci, dicacah-cacah berukuran sekitar $2 \mathrm{~cm}$, untuk selanjutnya dikukus selama sepuluh menit. Setelah dingin talas tersebut dicampur dengan ransum basal dengan proporsi sesuai perlakuan. Ransum diberikan dua kali sehari, pagi pada pukul 7.00 WIB dan sore pada pukul 16.00 WIB, sedangkan air minum diberikan ad libitum. Perlakuan pemberian talas dalam berbagai kombinasi daun, tangkai daun dan umbi digunakan $12,5 \%$.

Kelima perlakuan pemberian talas tersebut adalah :

P0 : sebagai kontrol, menggunakan $100 \%$ ransum basal tanpa menggunakan talas

P1 : $87,5 \%$ ransum basal $+12.5 \%$ talas $(35$ $\%$ daun $+40 \%$ tangkai daun $+25 \%$ umbi )

P2 : $87,5 \%$ ransum basal $+12,5 \%$ talas $(25$ $\%$ daun $+25 \%$ tangkai daun $+50 \%$ umbi )

P3 : $87,5 \%$ ransum basal $+12,5 \%$ talas $(12,5 \%$ daun $+12,5 \%$ tangkai daun $+75 \%$ umbi )

P4 : $87,5 \%$ ransum basal $+12,5 \%$ talas (100\% umbi)

Peubah yang diukur meliputi:

\section{Berat telur per butir}

Berat telur per butir diketahui dengan menimbang berat per butir telur

\section{Warna yolk}

Warna yolk diukur dengan memberikan skor berdasarkan yolk color fan

\section{Tebal kerabang telur}

Tebal kerabang telur diukur dengan menggunakan jangka sorong, diukur pada bagian ujung lancip, ujung tumpul, dan bagian tengah telur

\section{Komposisi fisik telur}

Komposisi fisik telur didapat dengan menghitung persentase yolk, albumen, dan kerabang telur terhadap bobot telur utuh. 
Tabel 1. Kandungan nutrisi bahan penyususn ransum

\begin{tabular}{lcccc}
\hline Bahan Penyususn Ransum & $\begin{array}{c}\text { Protein Kasar } \\
(\%)\end{array}$ & $\begin{array}{c}\text { Energi } \\
\text { Metabolis } \\
(\mathrm{kkal} / \mathrm{kg})\end{array}$ & Serat Kasar (\%) & Lemak (\%) \\
\hline Dedak & 10,45 & $1.856,49$ & 19,34 & 9,78 \\
Jagung & 8,55 & $3.105,66$ & 2,42 & 2,97 \\
Konsentrat Layer Khusus & 31,67 & 2800,00 & 9,83 & 6,73 \\
Daun Talas & 4,11 & 2918,25 & 13,28 & 4,44 \\
Tangkai Daun Talas & 3,02 & 2355,45 & 22,20 & 1,47 \\
Umbi Talas & 2,10 & 3420,23 & 2,59 & 0,69 \\
\hline
\end{tabular}

Tabel 2. Komposisi bahan penyusun ransum basal dan kandungan nutrisinya

\begin{tabular}{lc}
\hline Bahan Penyusun Ransum & Persentase \\
\hline Dedak (\%) & 31,5 \\
Jagung (\%) & 34,5 \\
Konsentrat Layer Khusus (\%) & 34,0 \\
Kandungan Nutrisi : & \\
Protein Kasar (\%) & 17,00 \\
Energi Metabolis (kkal/kg) & $2.608,78$ \\
Serat Kasar (\%) & 10,27 \\
Ether Extrac (\%) & 6,27 \\
\hline
\end{tabular}

Pengambilan data dilakukan setiap hari selama satu bulan. Data yang diperoleh dianalisis keragamannya, apabila perlakuan memberikan pengaruh nyata, untuk melihat perbedaan antar perlakuan dilakukan uji lanjut DMRT.

\section{HASIL DAN PEMBAHASAN}

\section{Berat telur per butir}

Ukuran telur menjadi tolok ukur harga sebutir telur itik; biasanya telur itik dengan ukuran besar mempunyai berat yang lebih tinggi sehingga harga per butir telurnya menjadi lebih mahal dibandingkan dengan telur yang berukuran kecil. Pengaruh pemberian talas terhadap rataan berat telur per butir ditampilkan pada Tabel 4.

Hasil analisis ragam menunjukkan bahwa berat per butir telur dipengaruhi secara nyata $(\mathrm{P}<0,05)$ oleh penggunaan talas dalam ransum. Hasil uji lanjut menunjukkan bahwa berat telur itik P0 yang tidak mendapat talas, nyata lebih rendah dibandingkan dengan $\mathrm{P} 2$, P3, dan $\mathrm{P} 4$, akan tetapi tidak berbeda nyata dengan P1. Terlihat dari Tabel 4. bahwa berat per butir telur pada itik yang diberi talas berkisar antara 63,03-65,41 g/butir adalah lebih tinggi dibandingkan dengan yang tidak diberi talas (P0) dengan berat telur per butir 60,14 g/butir. Hal ini menunjukkan bahwa penggunaan talas dalam ransum mampu meningkatkan berat per butir telur. Selanjutnya diantara itik yang mendapat perlakuan penggunaan talas, meskipun tidak berbeda secara nyata, semakin besar persentase pemberian bagian umbi akan menyebabkan semakin berat telur itik yang dihasilkan. Berat telur itik yang tanpa menggunakan talas 60,14 g, berat telur P1 dengan penggunaan bagian umbi $25 \%$ mencapai $63,03 \mathrm{~g}$, berat telur P2 dengan penggunaan bagian umbi $50 \%$ mencapai 63,63 g, berat telur P3 dengan penggunaan bagian umbi $75 \%$ mencapai 64,94g, dan berat telur P4 dengan pengguaan $100 \%$ bagian umbi mencapai 
65,41 g. Terlihat bahwa peningkatan penggunaan bagian umbi talas meningkatkan ukuran berat telur per butir. Peningkatan tertinggi terjadi pada telur itik dengan penggunaan bagian umbi $100 \%$. Bila dibandingkan dengan kontrol, penggunaan $100 \%$ bagian umbi dapat meningkatkan ukuran telur sebesar 8,65\%. Peningkatan ukuran berat telur ini disinyalir disebabkan oleh peningkatan kandungan energi ransum. Tabel 3 . memperlihatkan bahwa semakin tinggi penggunaan talas bagian umbi, kandungan energi ransum meningkat, dan hal ini diikuti oleh meningkatnya berat telur per butir.

\section{Warna Yolk}

Warna yolk merupakan salah satu faktor yang menentukan kualitas telur (Stadelman, 1997). Warna yolk yang disukai oleh kebanyakan konsumen adalah warna kuning tua dan tidak pucat. Warna yolk dapat diukur dengan memberikan skor warna berdasarkan warna standard Yolk Color Fan (Sudaryani, 2006). Rataan skor warna yolk itik Talang Benih selama penelitian disajikan pada Tabel 4. Hasil analisis ragam menunjukkan bahwa penggunaan talas dalam ransum berpengaruh secara nyata $(\mathrm{P}<0,05)$ terhadap skor warna yolk. Skor warna yolk itik P0 yang tidak mendapatkan talas $(5,38)$ nyata lebih rendah dibandingkan dengan itik yang mendapatkan talas P1 dengan skor 7,02, P2 dengan skor 7,03, P3 dengan skor 6,95, dan P4 dengan skor 6,90. Selanjutnya diantara itik yang mendapatkan talas, skor warna yolk itik P1 yang menggunakan daun 35\% dan tangkai daun $40 \%$ adalah 7,02 tidak berbeda dengan skor warna yolk P2 yang menggunakan daun $25 \%$ dan tangkai daun $25 \%$ yaitu 7,03 . Skor warna kuning telur P1 dan P2 ini lebih tinggi dibandingkan dengan P3 yang hanya menggunakan daun dan tangkai daun masing-masing 12,5\% maupun P4 yang tanpa menggunakan daun dan tangkai daun. Hal ini menunjukkan bahwa daun dan tangkai daun talas memberikan kontribusi dalam pewarnaan yolk. Peningkatan warna yolk akibat penggunaan talas ini masih jauh lebih rendah dibandingkan dengan penggunaan daun indigofera segar, sebagaimana hasil penelitian Akbarillah et al. (2005) yang menyatakan bahwa skor warna yolk dengan pemberian indigofera $5 \%-15 \%$ berkisar $11,63-11,91$.

\section{Tebal Kerabang}

Hasil analisis ragam menunjukkan bahwa penggunaan talas berpengaruh secara nyata $(\mathrm{P}<0,05)$ terhadap tebal kerabang telur. Tabel 4. menunjukkan bahwa tebal kerabang telur itik P1 (0,59 $\mathrm{mm}$ ) yang tidak menggunakan talas nyata lebih rendah dibandingkan perlakuan lain ( P1 0,65 mm, P2 0,65 mm, P3 0,66 mm, dan P4 0,64 mm). Hal ini mengindikasikan bahwa penggunaan talas dalam ransum itik dapat meningkatkan ketebalan

Tabel 3. Komposisi bahan penyusun ransum perlakuan dan kandungan nutrisinya

\begin{tabular}{lccccc}
\hline Bahan & \multicolumn{4}{c}{ Perlakuan } \\
\cline { 2 - 5 } & P0 & P1 & P2 & P3 & P4 \\
\hline Ransum Basal (g) & 170 & 148,75 & 148,75 & 148,75 & 148,75 \\
Daun Talas (g) & 0 & 7,44 & 5,31 & 2,66 & 0 \\
Tangkai Daun Talas (g) & 0 & 9,56 & 5,31 & 2,66 & 0 \\
Umbi Talas (g) & 0 & 5,31 & 10,63 & 15,94 & 21,25 \\
Kandungan Nutrisi & & & & 15,40 & 15,32 \\
Protein Kasar (\%) & 17,00 & 15,58 & 15,48 & 2968,12 & 3009,46 \\
Energi Metabolis (kkal/kg) & 2608,78 & 2906,57 & 2926,26 & 10,34 & 9,54 \\
Serat Kasar (\%) & 10,27 & 12,23 & 11,14 & & \\
\hline
\end{tabular}


Tabel 4. Pengaruh penggunaan talas terhadap berat per butir telur, skor Yolk dan tebal kerabang telur Itik Talang Benih

\begin{tabular}{llll}
\hline Perlakuan & $\begin{array}{l}\text { Berat Telur per Butir } \\
\text { (g/butir) }\end{array}$ & Skor Warna Yolk & Tebal Kerabang $(\mathrm{mm})$ \\
\hline P0 & $60,14 \pm 2,82 \mathrm{~b}$ & $5,38 \pm 0,23 \mathrm{~b}$ & $0,59 \pm 0,02 \mathrm{~b}$ \\
P1 & $63,03 \pm 1,25 \mathrm{ab}$ & $7,02 \pm 0,24 \mathrm{a}$ & $0,65 \pm 0,02 \mathrm{a}$ \\
P2 & $63,63 \pm 2,56 \mathrm{a}$ & $7,03 \pm 0,20 \mathrm{a}$ & $0,65 \pm 0,01 \mathrm{a}$ \\
P3 & $64,94 \pm 2,00 \mathrm{a}$ & $6,95 \pm 0,24 \mathrm{a}$ & $0,66 \pm 0,01 \mathrm{a}$ \\
P4 & $65,41 \pm 2,32 \mathrm{a}$ & $6,90 \pm 0,16 \mathrm{a}$ & $0,64 \pm 0,00 \mathrm{a}$ \\
\hline
\end{tabular}

Keterangan :

P0 : sebagai kontrol, menggunakan $100 \%$ ransum basal tanpa menggunakan talas

P1 : $87,5 \%$ ransum basal $+12.5 \%$ talas ( $35 \%$ daun $+40 \%$ tangkai daun $+25 \%$ umbi )

P2 : $87,5 \%$ ransum basal $+12,5 \%$ talas ( $25 \%$ daun $+25 \%$ tangkai daun $+50 \%$ umbi $)$

P3 : $87,5 \%$ ransum basal $+12,5 \%$ talas $(12,5 \%$ daun $+12,5 \%$ tangkai daun $+75 \%$ umbi $)$

P4 : $87,5 \%$ ransum basal $+12,5 \%$ talas (100 \% umbi)

kerabang telur. Belum diketahui secara pasti mekanisme terjadinya peningkatan ketebalan kerabang dengan penggunaan talas ini, disinyalir talas mengandung zat aktif yang dapat memperbaiki efisiensi metabolisme calsium sebagai komponen yang mempengaruhi ketebalan kerabang telur. Kekurangan kalsium pada unggas yang sedang produksi dapat menyebabkan tipisnya kerabang telur (Wahyu, 1992). Tebal kerabang telur pada penggunaan talas ini berkisar antara 0,64-0,66 mm, adalah lebih tebal dibanding tebal kerabang telur itik Talang Benih yang diberi indigofera segar (Tris Akbarillah, et al, 2005 ) dengan tebal kerabang 0,37-0,39 $\mathrm{mm}$.

\section{Komposisi Fisik Telur Itik}

Komposisi fisik telur dimaksud dalam penelitian ini meliputi persentase albumen (putih telur), persentase yolk, dan persentase kerabang telur.

Penggunaan talas dalam ransum berpengaruh secara tidak nyata $(\mathrm{P}>0,05)$ terhadap komposisi fisik telur Itik Talang Benih. Hal ini menunjukkan bahwa komposisi fisik telur tidak dipengaruhi oleh penggunaan talas dalam ransum. Tidak adanya pengaruh yang nyata ini diduga karena itik yang digunakan berumur sama. Pada umumnya ukuran tetur itik pada awalnya kecil kemudian meningkat dan akhirnya akan mengecil lagi saat mendekati masa akhir produksi (Kususiyah dan Kaharuddin, 2006). Menurut Amrullah (2003), kuning telur yang besar akan menghasilkan ukuran telur yang besar, sedangkan kuning telur yang kecil akan menghasilkan telur berukuran kecil. Persentase kuning telur Itik Talang Benih penelitian ini berkisar $31,16 \%-32,43 \%$ lebih tinggi bila dibandingkan dengan yang dilaporkan Hardjosworo (1989) bahwa persentase yolk Itik Tegal berkisar antara 28,21\%-28,84\%, dengan persentase albumen berkisar $58,89 \%-59,40 \%$ dan kerabang telur $12,18 \%$ $12,40 \%$.

\section{KESIMPULAN}

Penggunaan talas $12,5 \%$ dari ransum dengan berbagai komposisi pemberian bagian talas secara nyata meningkatkan berat telur itik per butir, memperbaiki warna kuning telur, dan meningkatkan tebal kerabang telur tapi tidak berpengaruh secara nyata terhadap komposisi fisik telur. 


\section{DAFTAR PUSTAKA}

Akbarillah, T., Kususiyah, dan Hidayat. 2005. Pengaruh penggunaan daun indigofera segar dalam ransum itik terhadap kualitas telur itik. Laporan Penelitian Universitas Bengkulu.

Amrullah, I. K. 2003. Nutrisi Ayam Petelur. Lembaga Satu Gunungbudi. Bogor.

Hardjosworo, P. S. 1989. Respon biologik Itik Tegal terhadap ransum pertumbuhan dengan berbagai kadar protein. Disertasi Fakultas Pasca Sarjana Institut Pertanian Bogor. Bogor

Kususiyah dan D. Kaharuddin. 2006. Respon produksi telur Itik Talang
Benih pada level protein ransum berbeda serta kajian kualitas telur dengan CPO sebagai sumber karoten. Laporan Penelitian. Universitas Bengkulu. Bengkulu.

Somantri, I. H. 2006. Mengenal Plasma Nutfah Tanaman Pangan. Badan Penelitian dan Pengembangan Pertanian. Departemen Pertanian Indonesia.

Suhardi. 2006. Hutan dan Kebun sebagai Sumber Pangan Nasional. Kanisius. Yogyakarta.

Stadelman, W. J. 1977. Egg Science and Tecnology. The Avipublising. Westport. Connecticut.

Sudaryani, T. 2006. Kualitas Telur. Penebar Swadaya. Jakarta. 